\title{
The Impact of Local Source Sediments on Bed Texture in the Fall River, Rocky Mountain National Park, USA
}

\author{
Jordan A. Clayton ${ }^{*}$ and Kristopher-Nelson Eby
}

Department of Geosciences, Georgia State University, P.O. Box 4105, Atlanta, GA 30302, USA

\begin{abstract}
The bed texture of a gravel-bed river is related to the size distribution and quantity of source sediments, the routing of sediment through the reach, and the distribution of flow velocity. A reach morphology that is consistent in depth with little lateral topographic variation will typically have a bed texture that is characterized by a fairly uniform grain size distribution. However, spatial variations in source sediments within a given watershed may impact the distribution of gravel-bed river sediments, even at the reach scale, such that two proximal reaches of the same river having the same general morphology can exhibit contrasting distributions of surface sediments. We collected extensive topographic and sedimentological data from two reaches of the Fall River in Rocky Mountain National Park, Colorado. These were chosen for their simple morphology (both are straight reaches with fairly uniform depths) and contrasting location relative to alluvial fan deposits that were introduced into the valley in a dam-break event in 1982; the upstream reach was unaffected by the introduced sediments. Despite the long duration since this event, surveying in 2008 revealed that the fan sediment continues to coarsen the left and upstream portions of the affected reach relative to other regions of the channel. The persistent nonuniformity in bed texture in the downstream reach may eventually result in morphological adjustment by promoting differential routing of fine versus coarse bed load size fractions, which may induce meandering.
\end{abstract}

Keywords: Bed texture, gravel-bed river, alluvial fan, channel morphology, spatial uniformity, fall river, rocky mountain national park.

\section{INTRODUCTION}

The morphology of a river channel strongly affects the spatial routing of sediment and its resulting bed texture [1]. Gravel bed rivers typically have a coarse surface layer that serves to protect a comparatively-finer subsurface sediment matrix from erosion [2]. The surface grains also provide an initial source area for the bed load sediment. As larger grains are picked up in the flow, grains of a similar size will tend to replace grains that were entrained in the flow. This process is largely dependent upon the sediment supply available within the river and upstream supplies [3-7]. If the sediment entering the reach is not equal to that which is leaving in volume and size, then the system may undergo geomorphic change [6].

In curved channels, fine and coarse grains tend to be routed towards the inside and outside regions of the bend, respectively $[8,9]$. This differential routing of sediment is a function of the channel shape, and leads to spatial variations in the bed texture that may persist over a large range of flows [6]. Other examples of nonuniform reach topography, such as channel bifurcations, expansions, or other complexities, also play a major role in the routing of sediment within the channel because these produce lateral differences in depth that drive flow accelerations across the channel [10] which, in turn, promote reach-scale surficial grain size sorting and patchiness [11].

In contrast, for relatively straight, rectangular-shaped reaches with uniform depths, the spatial distribution of bed

*Address correspondence to this author at the Department of Geosciences, Georgia State University, P.O. Box 4105, Atlanta, GA 30302, USA;

Tel: (404) 413-5791; E-mail: jclayton@gsu.edu sediment should be fairly uniform [12]. Straight channels with no lateral topography lack significant cross-channel flow and therefore lack mechanisms to substantially alter streamwise-oriented bed load transport pathways. As a result, the expected surface texture in straight, rectangular reaches tends to be a fairly evenly-distributed mixture of the full range of grain sizes present in the supply from upstream.

However, even for geomorphically-simple channel reaches with uniform depths, the introduction of local sediment can strongly influence the distribution of bed grains $[13,14]$. Local sediment sources can greatly alter the distribution of sediment in a reach, especially if they significantly differ in grain size distribution from upstream source areas $[15,16]$. This paper explores spatial differences in surface texture within an individual stream reach that result from the incorporation of comparatively coarse alluvial fan sediment along the left margin of the channel, and are unrelated to channel morphology. Our study builds upon many reports $[15,17-20]$ that examine longitudinal grain size variations by focusing on local supply-induced variations in bed texture at the subreach scale.

To examine the influence of local sediment sources on the distribution of bed sediments, we investigated two straight reaches of the Fall River in Rocky Mountain National Park (RMNP) (Fig. 1). Reach one (R1) is a "pristine" site, located roughly one kilometer upstream of a large alluvial fan that was deposited in a discrete event (from a failure of an earthen dam on a tributary of the Fall River) in July of 1982 (see details in [21]). The only apparent sediment sources are from upstream alluvial material and from the banks and hill slopes. R1 therefore serves as a control in this examination of the effect of local supply on 
reach sedimentology. Reach two (R2), is located slightly downstream from R1 and on the opposite side of the valley from the alluvial fan (Fig. 1) and was therefore impacted from the introduction of sediments in the 1982 event and thereafter. The alluvial fan deposits directly affect the Fall River in that they comprise much of the material on the left bank of R2. We describe herein the effect of this spatial difference in sediment supply on bed sediment distribution, and we explore potential future adjustments in channel morphology.

\section{SITE LOCATION AND BACKGROUND}

Located in Rocky Mountain National Park (RMNP) in northern Colorado, the Fall River meanders through Horseshoe Park, a long, formerly-glaciated U-shaped valley. The valley is comprised mainly of late Pleistocene and early Holocene alluvial sediments [22] and is bounded on both sides by large lateral Quaternary moraines. The Fall River has a gravel-bed and stable, lightly-vegetated banks in most places [23]. The annual hydrograph is dominated by late spring snowmelt runoff.

Lawn Lake is a naturally-formed, high elevation lake near the headwaters of the Roaring River, a tributary to the Fall River that has its confluence in Horseshoe Park at approximately $2606 \mathrm{~m}$ asl [24]. In the early 1900s (prior to the establishment of RMNP), local farmers decided to enhance the lake's storage capacity and constructed an earthen dam that more than tripled the volume of water stored in Lawn Lake. In subsequent years the dam fell out of regular inspection due, in part, to the nearly $10 \mathrm{~km}$ hike required to visit the site [25]. On the morning of 15 July, 1982 , the dam failed, releasing approximately 831,000 cubic meters of stored water [24]. Peak outflows were roughly 510 $\mathrm{m}^{3} / \mathrm{s}$, and floodwaters scoured the Roaring River channel bed and valley margins, transporting sand to boulder-size particles and other debris into Horseshoe Park [26, 27], burying roughly a kilometer of the Fall River [21]. The majority of flood-transported materials were deposited into a large alluvial fan, creating Fan Lake (Fig. 1) from the partial impoundment of the Fall River. For safety reasons, in 1995 the outlet of Fan Lake was enlarged by RMNP personnel to drain the lake and begin restoring the valley [28].

The abundant supply of sand, gravel, and cobbles throughout the valley made Fall River an excellent location to examine the relationship between channel morphology, bed texture, and local sediment sources. To isolate the influence of local sediment sources on stream bed texture, we investigated two distinct reaches of the Fall River. The first site (R1) was located well-upstream of the alluvial fan and Fan Lake. This section of the river was therefore completely unaffected by the flood and served as a control for the balance between the bed texture and channel morphology where the only sediment supply is from upstream sources. The second site (R2) was downstream from R1 and was located across the valley from the majority of the alluvial fan deposits; sand and gravel deposited during

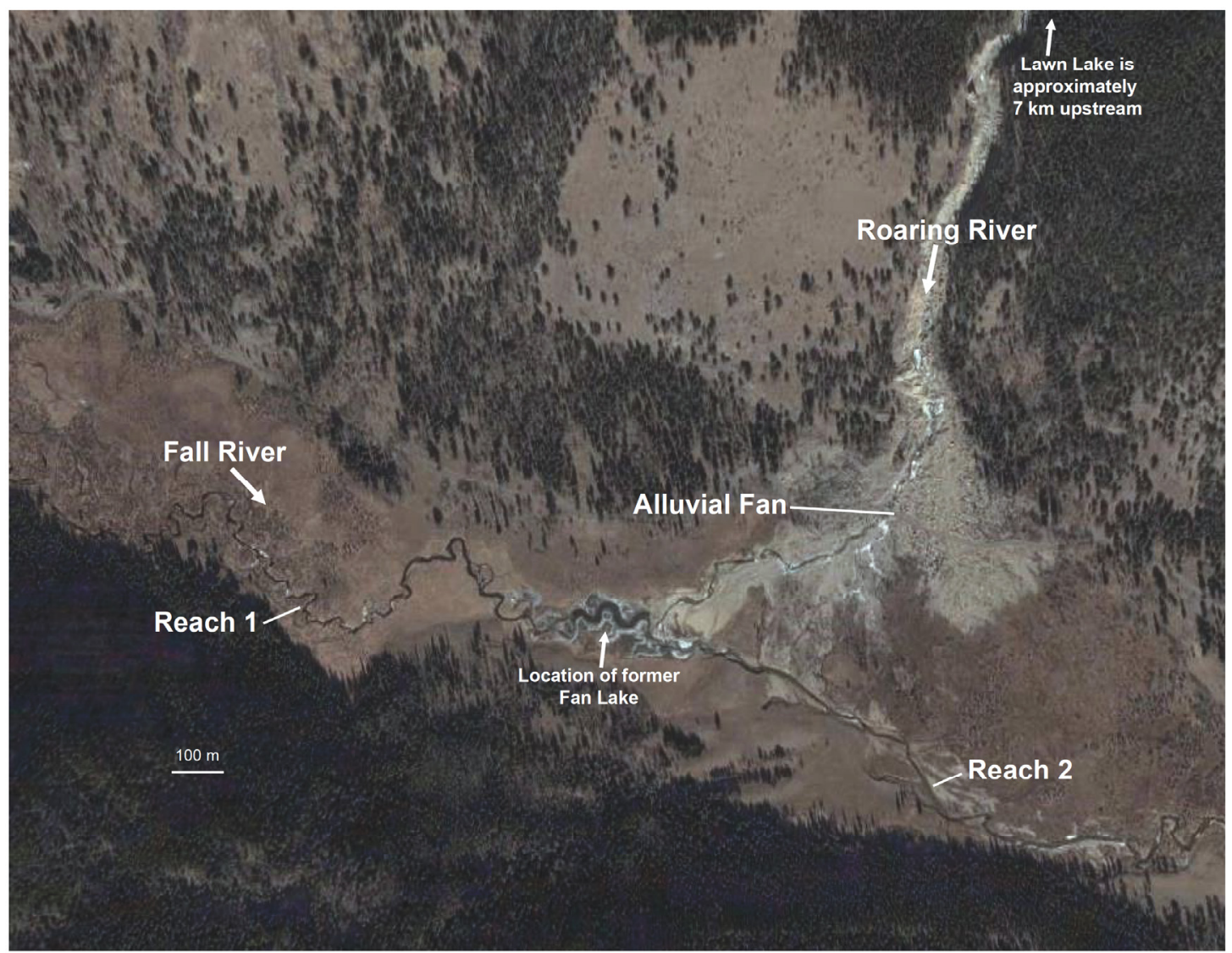

Fig. (1). Satellite image showing the geography of the Horseshoe Park area in Rocky Mountain National Park, including the alluvial fan and reaches 1 and 2. Image is centered on $40^{\circ} 24^{\prime} 35^{\prime}$ N, $105^{\circ} 38^{\prime} 23^{\prime \prime} \mathrm{W}$ and was taken on November 5, 2004, copyright DigitalGlobe ${ }^{\circ}$. Flow direction is indicated with the arrows for Fall River and Roaring River. Obtained from Google Earth ${ }^{\circ}$. 
the 1982 event extend to the river's left bank (Fig. 1). The confluence of the Fall and Roaring Rivers occurs roughly 0.5 $\mathrm{km}$ upstream of R2; sediments derived from the Roaring River headwater areas would have become thoroughly integrated with other Fall River basin sediments before entering R2. This site therefore serves to examine the effect of a local sediment source on the texture and morphology of the Fall River and its relative stability over longer timescales.

\section{METHODS}

Detailed information on channel topography, surface sediments, and sediment supply was obtained for R1 and R2. Topographic data was obtained using a Nikon NPL-352 total station to survey cross sections spaced no more than onethird channel width apart. These data were later input into a flow model (U.S. Geological Survey multi-dimensional surface water modeling system (MD-SWMS), [29]) to generate a three-dimensional surface for both reaches. Bankfull height was determined from topographic breaks in slope and from changes in vegetation. The water-surface slope was measured with the total station by extending the survey longitudinally several reach lengths beyond each site.

The channel's bed surface texture was quantified using a modified version of the Wolman [30] pebble-count method: each sample included 50, not 100 , particles. The use of 50 particles represented a compromise between maintaining a sample size large enough to produce statistically-reliable grain size distributions and the need to sample a large number of locations $[9,11]$. Combining both research sites, 58 pebble counts were taken at 33 different cross-sections, resulting in the characterization of 2900 total grains. For each count, individual particles were randomly sampled from the riverbed and their size was measured using a gravelometer, a metal template with openings at half-phi intervals designed to measure the size of a grain's middle axis. At least two pebble counts were taken at each crosssection; these were staggered evenly throughout the reach to adequately characterize the bed texture.

In addition to the pebble counts, four bulk samples of exposed floodplain sediment were taken at the downstream location to compare the grain size composition of left and right bank, as well as upstream, sediment sources. Left bank samples were located one-third, halfway, and two-thirds the streamwise distance downstream from the upper end of the reach (cross sections 4,8 , and 12 , respectively), and the right bank sample was also located at cross section 4. All samples were obtained roughly one meter away from the top of the bank. Individual grains larger than $32 \mathrm{~mm}$ were sieved and counted in the field; sufficient material was sampled to ensure that the largest grain size recorded did not represent more than $2 \%$ of the total weight of the sample [31], and that samples were not biased by any individual coarse grains. Grains finer than $32 \mathrm{~mm}$ were weighed, and a sample of this material was preserved for particle size analysis using a RoTap sieve shaker in the laboratory.

To evaluate differences in the distribution of bed sediments in the experimental and control stream reaches, we ran t-tests to compare the $\mathrm{D}_{84}, \mathrm{D}_{50}$, and the $\mathrm{D}_{16}$ of samples obtained from the left versus right, and upstream versus downstream, portions of both channels. The $\mathrm{D}_{84}, \mathrm{D}_{50}$, and the
$D_{16}$ represent the grain size for which 84,50 , and 16 percent of the size distribution is finer, respectively. Significant difference between samples was determined from $p<0.05$.

\section{RESULTS}

The topographic characteristics of Reach 1 were obtained from 12 surveyed cross-sections spaced roughly $1.5 \mathrm{~m}$ apart; the reach morphology is illustrated in Fig. (2). Reachaverage bankfull width and depth were 9.6 and $0.4 \mathrm{~m}$,

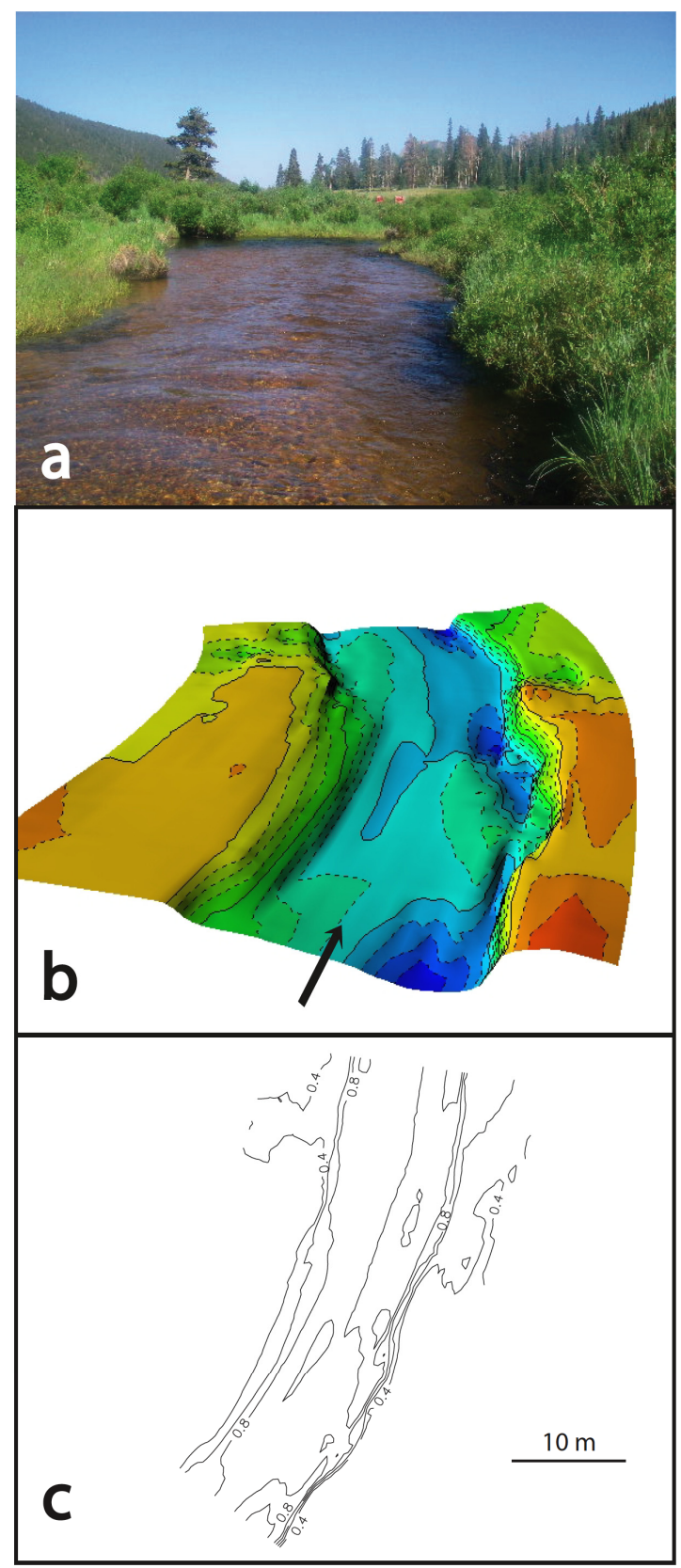

Fig. (2). View of Reach 1, taken at approximately mid-reach (a), three-dimensional modeled surface developed using MD-SWMS software (b), and topographic map of reach using $0.2 \mathrm{~m}$ contour interval (c). Flow direction is indicated by the arrow. High and low elevation areas are represented by red to blue colors, respectively, for (b) and for Fig. (4b).

respectively, and the water surface slope was 0.004 . From 23 pebble counts performed in $\mathrm{R} 1$, the reach-average $\mathrm{D}_{84}, \mathrm{D}_{50}$, 
and $\mathrm{D}_{16}$ was $34.3,22.5$, and $14.1 \mathrm{~mm}$, respectively. The coefficient of variation, or CV (determined as the standard deviation divided by the mean sediment size, giving a normalized value of particle size variability) for the sample $\mathrm{D}_{84}$ values was 0.15 , suggesting that textural variation was minimal for the coarse size fractions present on the bed. Similarly, the CV was 0.17 and 0.23 for the $D_{50}$ and $D_{16}$ values, respectively. All $\mathrm{CV}$ values obtained for R1 were relatively small, indicating that the grain size distribution of bed sediments did not vary substantially through the reach. The frequency of sample $\mathrm{D}_{84}$ values is shown in Fig. (3).

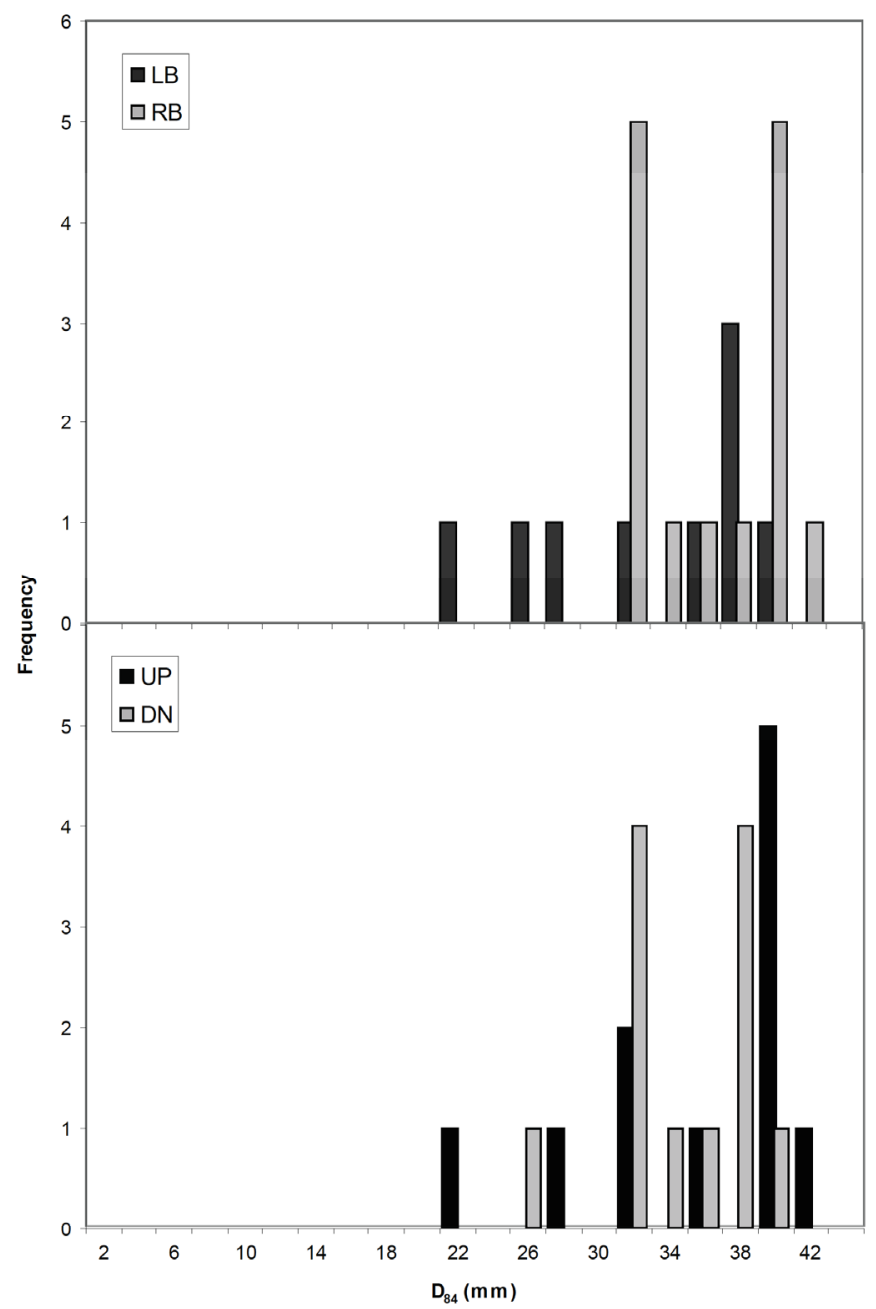

Fig. (3). Frequency of $D_{84}$ values from different regions of Reach 1: left and right portions of the channel (LB and RB, respectively) and upstream and downstream regions (UP and DN, respectively). Bin width is $2 \mathrm{~mm}$.

T-test analysis of differences in the bed texture between left and right portions of R1 indicated that the sample $D_{84}$ and $\mathrm{D}_{50}$ values were not statistically different (Table 1), which is consistent with expectations for a straight reach and uniformly-distributed sediment supply. Contrastingly, there was a significant difference in the distribution of fine grain sizes $\left(D_{16}\right)$ between left and right portions of the reach $(p=$ 0.018 ), which may be related to the short reach length, the bar-pool morphology of proximal reaches of the river, or some other factor.
Table 1. Probability Values Associated with t-Tests Comparing Grain Size Percentiles of Surface Samples Taken at Left and Right Portions of the Channel ( $L$ and $R$, Respectively), as Well as for Upstream Versus Downstream Regions (U and D, Respectively)

\begin{tabular}{|c|c|c|c|}
\hline \multirow{2}{*}{ Location } & \multicolumn{3}{|c|}{ Grain Size Percentile } \\
\cline { 2 - 4 } & $\mathbf{D}_{\mathbf{8 4}}$ & $\mathbf{D}_{\mathbf{5 0}}$ & $\mathbf{D}_{\mathbf{1 6}}$ \\
\hline \hline Reach 1: L,R & $\mathbf{0 . 2 0 9}$ & $\mathbf{0 . 0 5 8}$ & 0.018 \\
\hline Reach 1: U,D & $\mathbf{0 . 7 6 5}$ & $\mathbf{0 . 6 8 9}$ & $\mathbf{0 . 6 8 4}$ \\
\hline Reach 2: L,R & 0.022 & 0.001 & 0.016 \\
\hline Reach 2: U,D & 0.011 & 0.010 & 0.001 \\
\hline
\end{tabular}

The values in bold are for samples that were not significantly different (i.e. where there was spatial uniformity in bed texture), while the other values correspond to significant differences between samples (i.e. where spatial variations in bed texture were significant).

We also compared the character of the surficial sediments from upstream and downstream portions of R1. Given the channel's rectangular and straight morphology, our expectation was that the distribution of sediment sizes ought to be fairly consistent in both the lateral and longitudinal directions. For R1, the probability values associated with the t-tests comparing upstream and downstream portions of the channel were $0.765,0.689$, and 0.684 for the $\mathrm{D}_{84}, \mathrm{D}_{50}$, and $\mathrm{D}_{16}$ grain sizes, respectively (Table 1), which is consistent with our suggestion that straight reaches of this type lack mechanisms to preferentially sort particles into discrete patches or other non-uniform textures.

Reach 2 was somewhat larger than Reach 1, with a bankfull width and depth of 12.5 and $0.8 \mathrm{~m}$, respectively, and water surface slope of 0.005 (Fig. 4). Seventeen crosssections were spaced roughly $4 \mathrm{~m}$ apart through the $70 \mathrm{~m}$ long reach. We performed 35 pebble counts in R2, giving reach-average $D_{84}, D_{50}$, and $D_{16}$ values of $68.9,42.6$, and $22.8 \mathrm{~mm}$, respectively. All represent increases from reachaverage grain size percentiles obtained from Reach 1 (Fig. 5). The $C V$ for the reach-average $D_{84}, D_{50}$, and $D_{16}$ values was $0.20,0.18$, and 0.19 , respectively. These suggest that even though there was an increase in the actual size of sediment being transported in the channel, there was only a marginal increase in the relative range of values.

Probability values associated with t-tests comparing left and right portions of the channel for R2 were $0.022,0.002$, and 0.016 for the $\mathrm{D}_{84}, \mathrm{D}_{50}$, and $\mathrm{D}_{16}$, respectively, implying that samples from these two regions are significantly different for all grain size fractions considered (Table 1). This spatial difference is illustrated in Fig. (6) which gives the frequency of sample $\mathrm{D}_{84}$ values for left and right portions of the channel. Moreover, the $\mathrm{D}_{84}, \mathrm{D}_{50}$, and $\mathrm{D}_{16}$ values for the bulk sample taken from the exposed floodplain sediments at cross section 4 along the right bank of the channel were $22.5,7.2$, and $0.9 \mathrm{~mm}$, respectively. These potential source sediments for the right portion of the channel are significantly finer than floodplain sediments exposed along the left side of the reach; the mean of the $\mathrm{D}_{84}, \mathrm{D}_{50}$, and $\mathrm{D}_{16}$ 


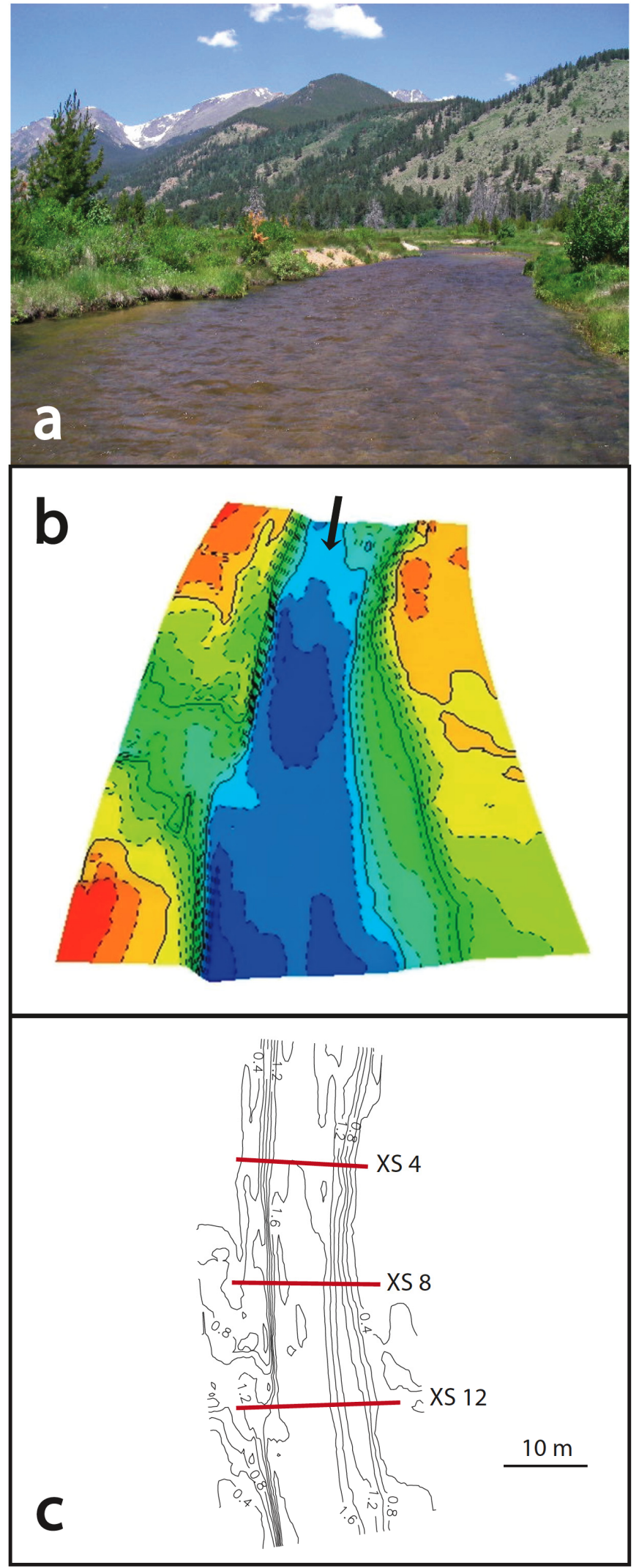

Fig. (4). View of Reach 2, taken at approximately mid-reach (a), three-dimensional modeled surface developed using MD-SWMS software (b), and topographic map of reach using $0.2 \mathrm{~m}$ contour interval (c). Flow direction is indicated by the arrow. XS 4, 8, and 12 refer to cross-sections where substrate grain size distribution samples were collected. values associated with the three samples of exposed floodplain sediment from the left side of the channel were $44.2,9.6$, and $0.7 \mathrm{~mm}$, respectively.

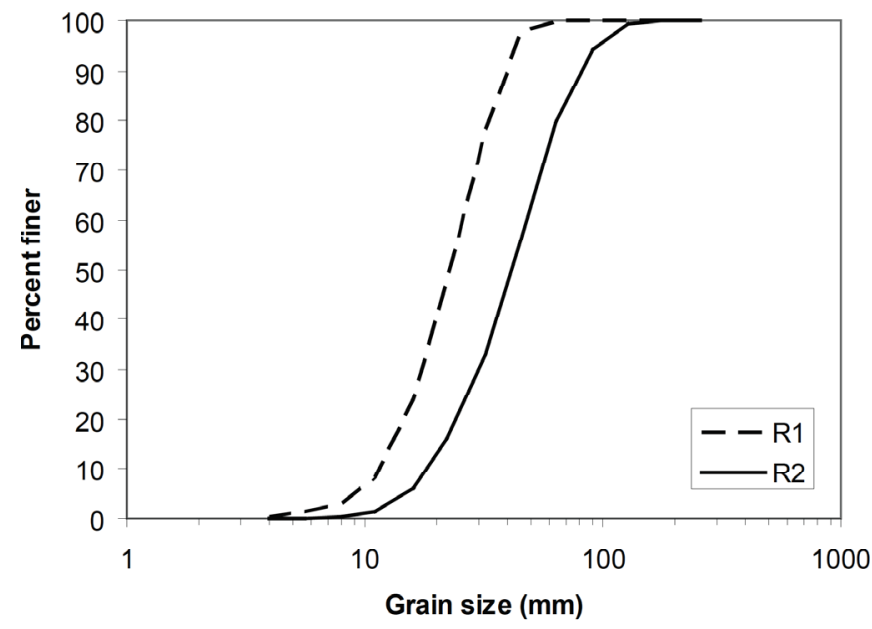

Fig. (5). Grain size distributions for Reach 1 and 2. These are reach-average values from individual grain size distributions obtained from the 58 total pebble counts.

Not surprisingly, the coarse size fraction of the floodplain sediments (represented by the $\mathrm{D}_{84}$ ) became rapidly finer with distance from the alluvial fan, ranging from $61.4 \mathrm{~mm}$ at the upstream end to $12.3 \mathrm{~mm}$ near the downstream end of the reach. The rapid decline in grain size percentiles through the reach seems well-explained by the orientation of the reach (and floodplain samples) relative to the alluvial fan (Fig. 1).

Probability values associated with t-tests comparing river bed sediments in upstream and downstream portions of R2 were less than 0.05 for the $D_{84}, D_{50}$, and $D_{16}$ (Table 1), indicating that differences in the size of sediment from the upstream and downstream regions were statistically significant. The mean of the $\mathrm{D}_{84}, \mathrm{D}_{50}$, and $\mathrm{D}_{16}$ values associated with the upstream portion of the reach were 74.5 , 45.7, and $25.1 \mathrm{~mm}$, respectively; these declined to 62.9 , 39.2 , and $20.4 \mathrm{~mm}$, respectively, for the downstream region. These results strongly suggest that the textural variations observed in R2 were caused by the introduction of locallyavailable sediment from the alluvial fan, and that this sediment supply continues to affect reach sedimentology.

\section{DISCUSSION}

For R1, the field data generally matched our expectations for the reach. Because the morphology of the channel was more or less uniform in depth, the flow was hydrostatic with vectors of fluid stress oriented predominantly longitudinally. We therefore expected the distribution of sediment to vary little through the reach. We found both a general uniformity in the distribution of surficial sediments, and also a small overall range of sediment sizes present in the reach. Given the location of R1 well-upstream from the alluvial fan deposits, there appeared to be no local sources of sediment affecting the reach, meaning that the feed of sediment to the reach consists of integrated supply materials from upstream portions of the watershed and from the streambanks. Given this context, it served as both a model of what might be expected where there is a balance of flow, sediment transport, and channel morphology in a straight, rectangular 


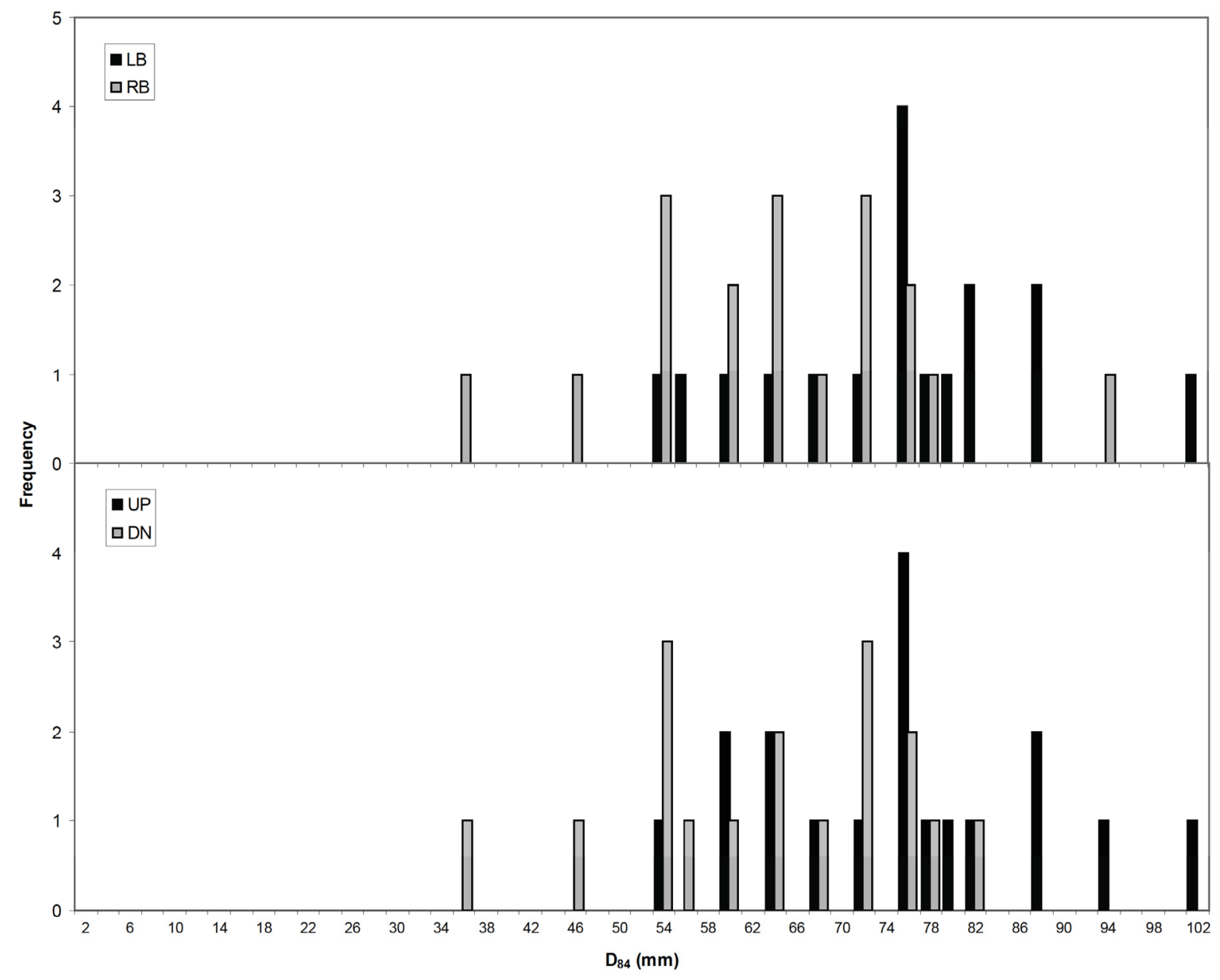

Fig. (6). Frequency of $\mathrm{D}_{84}$ values from different regions of Reach 2. Symbols and bin width are the same as for Fig. (3).

reach and an experimental control against which to compare spatially-varying surficial sediments in R2.

Conversely, for Reach 2 the left side of the river was cutting through deposits from the alluvial fan, while the right side of the river was comparatively unaffected by the 1982 event. The sediment available to replenish entrained particles in the right-hand portion of the channel would have been relict outwash (from the stream banks) and upstream watershed materials, and to a lesser degree, the alluvial fan sediments. The fan sediment on the left bank was both coarser and more abundant (Fig. 7); this disparity apparently continues to drive spatial differences in the channel's surface texture. These results also provide evidence that very little lateral mixing of grain sizes currently occurs within the reach.

The distribution of grain sizes observed in the channel of R2 mirror the bulk sediment data from exposed floodplain sediments on both the left and right bank of the channel, strongly suggesting that these serve as the principal sources of bed load sediment for the reach. This analysis indicates that the alluvial material brought into the valley from the Lawn Lake failure disproportionately impacts the channel at the most upstream portion of the reach; with increasing distance from the area of impact, the average grain size rapidly decreases. Orvis and Graham [24], Table 1 estimate that the

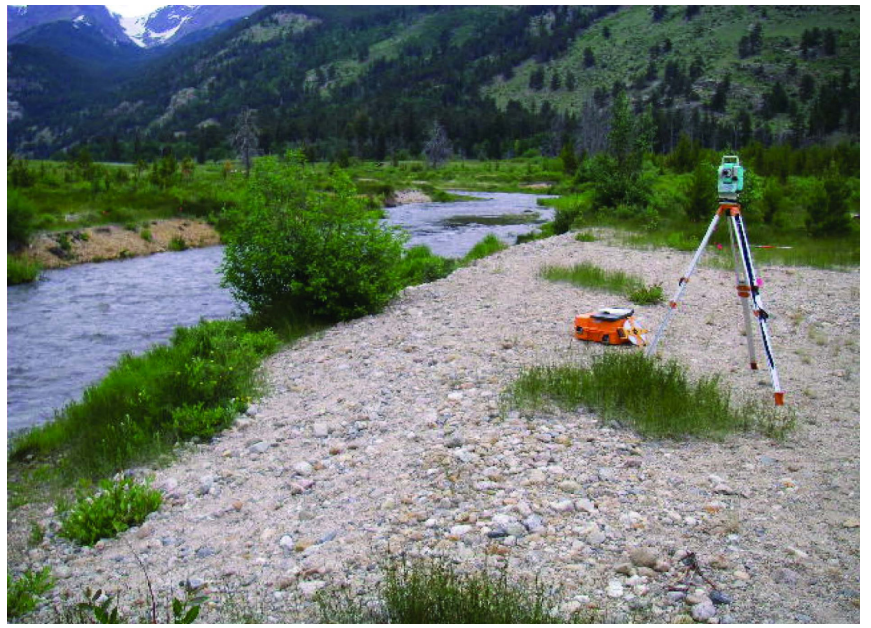

Fig. (7). Coarse alluvial fan sediments from the 1982 event still clearly exposed along the left bank of Reach 2 . Picture taken during the 2008 field season. View is upstream.

competent particle size (see also [32]) of floodwaters during the Lawn Lake 1982 event decreased from roughly 0.411 to 0.035 $\mathrm{m}$ over only around 0.7 kilometers of valley length from the alluvial fan's origin in Horseshoe Park. R2 is approximately 0.4 $\mathrm{km}$ downstream from the fan, indicating that the largest particle size transported by the 1982 event at R2 would correspond to $0.19 \mathrm{~m}$ at the upstream end of the reach and that the competent 
strength of the flow would decline significantly through the reach, resulting in a maximum competent particle size of $0.15 \mathrm{~m}$ at the downstream end. The maximum grain size we measured in R2 was $0.180 \mathrm{~m}$ (10 total), which falls in between these values; more subtle differences in competent grain size may have been lost due to the use of $1 / 2$ phi interval grain size intervals.

While we lack quantifiable data to evaluate the distance downstream from R2 required to allow sediments to become fully laterally mixed, visual observations suggest that full mixing had occurred within several reach lengths. Lateral mixing is aided in downstream reaches by the onset of a migrating channel planform, which is accompanied by substantial lateral topography and (presumably) cross-channel sorting of grain sizes. Farther $(1 \mathrm{~km})$ downstream, a reach described in [11] has a well-mixed, fairly uniform gravel bed texture (reach average $\mathrm{D}_{50}=30 \mathrm{~mm}$, bankfull width and depth of $12 \mathrm{~m}$ and $0.6 \mathrm{~m}$, respectively) with little, if any, lateral variability in surface grain size distribution.

The introduction of larger material affects the distribution of roughness through the reach because bed roughness $\left(\mathrm{z}_{0}\right)$ is a linear function of the local $\mathrm{D}_{84}$ [33]. Using data from a nearby site, [6] showed that the bed texture of a gravel-bed river may persist during large flow events, which reinforces the effect that local sediment sources may have on the long-term sedimentology of stream reaches. Persistent roughness differences between regions of the channel may drive future shifts in channel morphology, such as the onset of lateral migration. Many of the coarse grains we measured in R2 appeared to have not moved from their location for some time, probably since the last bankfull flow. Immobility was suggested from accumulations of algae on the coarse particles and the partial infilling of fine sediments in between grains that were mainly located in the left portion of the channel. Contrastingly, the right portion of the channel had a finer bed texture, and surface grains lacked surficial algae, were looser, and appeared to have been recently mobilized. Other factors being equal, fine (coarse) sediment patches - at least relative to the reach median grain size - may be associated with lowered (greater) local critical Shields stress where they occur in moderately deep areas of the channel [11]. Given this configuration, it seems likely that, in the absence of flows capable of mobilizing the coarse grains found in the left region of the channel, the annual snowmelt flood will allow the river to progressively scour the right-hand portion of the bed (similar to experimental result by [34]). This, in turn, may induce an alternating bar pattern and eventual planform meandering as long as the reach-scale topographic perturbation persists [35]. The orientation of the river relative to the 1982 disturbance may therefore promote an eventual shift in local channel morphology; this underscores the role of dam-break floods as landscape disturbances able to drive persistent morphological change [36, 37].

\section{CONCLUSIONS AND FUTURE RESEARCH}

This work builds upon studies of local sediment inputs and their effect on the longitudinal grain size distribution of gravel rivers $[13,14,38]$, and others, by focusing on spatial variations that arise in bed texture within a reach when locally available sediments are limited to one side of the river channel (see also [39]). Two reaches of the Fall River in Rocky Mountain National Park with simple morphologies but contrasting surface grain size patterns illustrate the effect of local sediment sources (e.g. alluvial fan sediments) on a river's bed texture. For the downstream site, fan-introduced sediments were significantly coarser than comparatively-unimpaired sections of the channel. The sediment supply for the upstream site consisted of expected watershed and channel bed sources, resulting in a fairly even distribution of sediment sizes throughout the reach.

If the morphology of a channel is rather simple and rectangular, surficial sediments should be fairly uniformly distributed throughout the reach because differential transport induces spatial patchiness in bed texture [40] and is typically driven by the existence of lateral topography [8-10]. However, spatial variations in sediment sources lead to lateral and longitudinal variations in the distribution of sediment- even in straight river reaches [14]. The magnitude of such spatial variations in bed texture will be based on the scale of difference that exists between watershed and local-scale sediment sources. Additional data regarding the grain size composition of sediment sources are needed to evaluate such differences in supply.

These results underscore the importance of careful characterization of the size and distribution of sources of sediment to a given reach, as spatial variations that exist for such sources may be reflected in the channel's bed texture. Moreover, changes in the balance between these variables may ultimately affect the equilibrium morphology of the channel. Sufficiently long field studies or experiment investigations are needed to thoroughly examine the influence of spatial differences in reach roughness that arise due to persistent variations in surface texture on channel planform evolution.

Understanding the mechanisms that drive flow and sediment distribution in a river has a number of valuable applications, including the incorporation of process mechanics into physical river restoration efforts [41, 42], habitat suitability assessment for benthic invertebrates and other fauna [17, 43], and improved ability to model the distribution of surface sediments and channel dynamics in natural gravel-bed rivers [44, 45]. Additionally, these results may help researchers forecast spatial variations in the grain size distribution of buried sediment beds and other sedimentological features, with important implications for geological engineering (e.g. construction of building foundations, tunneling, and other activities). Possible future research questions include investigation into the increased range of $D_{16}$ values in R1, predicting and measuring future geomorphic changes in R2 as it re-stabilizes from the introduction of an outside sediment source, and examining the effects that larger grain sizes have on benthic invertebrate communities in the channel.

\section{ACKNOWLEDGEMENTS}

We thank the Georgia State University Ronald E. McNair program for providing funding and support for field work and data processing. We also thank the Rocky Mountain National Park personnel for allowing access to our field areas and for assistance with data collection. This manuscript was greatly improved from the thoughtful comments provided by two anonymous reviewers. This research was supported in part by a Georgia State University Research Initiation Grant obtained by the first author.

\section{CONFLICT OF INTEREST}

None declared. 


\section{REFERENCES}

[1] Ferguson RI. The missing dimension: Effects of lateral variation on 1-D calculations of fluvial bedload transport. Geomorphology 2003; 1332: $1-14$.

[2] Parker G, Klingeman PC. On why gravel bed streams are paved. Water Resour Res 1982; 18: 1409-1423.

[3] Hoey TB, Ferguson RI. Controls of strength and rate of downstream fining above a river base level. Water Resour Res 1997; 33: 2601-2608.

[4] Buffington JW, Montgomery DR. Effects of sediment supply on surface textures of gravel-bed rivers. Water Resour Res 1999; 35; 35233530 .

[5] Wilcock PR, DeTemple BT. Persistence of armor layers in gravel-bed streams. Geophys Res Lett 2005; 32: L08402.

[6] Clayton JA, Pitlick J. Persistence of the surface texture of a gravel-bed river during a large flood. Earth Surf Proc Landf 2008; 33: 661-673.

[7] Nelson PA, Venditti JG, Dietrich WE, Kirchner JW, Ikeda H, Iseya F, Sklar LS. Response of bed surface patchiness to reductions in sediment supply. J Geophys Res 2009; 114: F02005.

[8] Dietrich WE, Smith JD. Bed load transport in a river meander. Water Resour Res 1984; 20: 1355-1380.

[9] Clayton JA, Pitlick J. Spatial and temporal variations in bed load transport intensity in a gravel-bed river bend. Water Resour Res 2007; 43: W02426.

[10] Whiting PJ, Dietrich WE. Convective accelerations and boundary shear stress over a channel bar. Water Resour Res 1991; 27: 783-796.

[11] Clayton JA. Local sorting, bend curvature, and particle mobility in meandering gravel-bed rivers. Water Resour Res 2010; 46: W02601.

[12] Powell DM, Ashworth PJ. Spatial pattern of flow competence and bed load transport in a divided gravel bed river. Water Resour Res 1995; 31 : 741-752

[13] Knighton AD. Longitudinal changes in size and sorting of stream-bed material in four English rivers. Geol Soc Am Bull 1980; 91: 55-62.

[14] Rice S. Which tributaries disrupt downstream fining along gravel-bed rivers? Geomorphology 1998; 22: 39-56.

[15] Rice S, Church M. Grain size along two gravel-bed rivers: statistical variation, spatial pattern and sedimentary links. Earth Surf Proc Landf 1998; 23: 345-363.

[16] Whiting PJ, King JG. Surface particle sizes on armoured gravel streambeds: effects of supply and hydraulics. Earth Surf Proc Landf 2003; $28: 1459-71$.

[17] Rice SP, Greenwood MT, Joyce CB. Tributaries, sediment sources, and the longitudinal organisation of macroinvertebrate fauna along river systems. Can. J Fish Aq Sci 2001; 58: 824-840.

[18] Surian N. Downstream variation in grain size along an Alpine river: analysis of controls and processes. Geomorphology 2002; 43: 137-149.

[19] Rengers F, Wohl E. Trends of grain sizes on gravel bars in the Rio Chagres, Panama. Geomorphology 2007; 83: 282-293.

[20] Heitmuller FT, Hudson PF. Downstream trends in sediment size and composition of channel-bed, bar, and bank deposits related to hydrologic and lithologic controls in the Llano River watershed, central Texas, USA. Geomorphology 2009; 112: 246-260.

[21] Pitlick J. Response and recovery of a subalpine stream following a catastrophic flood. Geol Soc Am Bull 1993; 105: 657-670.

[22] Braddock WA, Cole JC. Geologic map of Rocky Mountain National Park and Vicinity, Colorado. U.S. Geological Survey, Miscellaneous Investigations Series Map I-1973, 1990.

[23] Anthony DJ, Harvey MD. Stage-dependent cross-section adjustments in a meandering reach of Fall River, Colorado. Geomorphology 1991; 4: $187-203$.
[24] Orvis CJ, Graham WJ. Geomorphic effects of the Lawn Lake dam failure: 1991: Proceedings of the $5^{\text {th }}$ Federal Interagency Sedimentation Conference, Las Vegas, USA 1991; 5FISC-14; 1-8.

[25] Estes Park. The Lawn Lake Flood. Estes Park, CO; 2008. [cited 2010 January 17]. Available from: www.estesnet.com/Hydroplant/the_lawn_ lake_flood.aspx

[26] Jarrett RD, Costa JE. Hydrology, geomorphology and dam-break modeling of the July 15, 1982 Lawn Lake Dam and Cascade Lake Dam failures. , Larimer County, Colorado. U.S. Geological Survey, Professional Paper 1369; 1986.

[27] Costa JE. In: Baker VR, Kochel R, Patton P, Eds. Flood Geomorphology. New York NY: Wiley 1988; pp. 439-463.

[28] Cooper DJ, Gage EA. Fan Lake and Fall River restoration: Site characterization, design elements, and recommendations. Report prepared for Rocky Mountain National Park, National Park Service Water Resources Division 2006.

[29] McDonald RR, Nelson JM, Bennett JP. Multi-dimensional surfacewater modeling system user's guide. U.S. Geological Survey, Techniques and Methods 6-B2; 2005.

[30] Wolman MG. A method of sampling coarse river-bed material. Trans Am Geophys U 1954; 35: 951-956.

[31] Church M, McLean DG, Wolcott JF. In: Thorne CR, Bathurst JC, Hey RD, Eds. Sediment Transport in Gravel-Bed Rivers. New York, NY: Wiley 1987; pp. 43-79.

[32] Schvidchenko AN, Pender G. Flume study of the effect of relative depth on the incipient motion of coarse uniform sediments. Water Resour Res 2000; 36: 619-628.

[33] Whiting PJ, Dietrich WE. The roughness of alluvial surfaces: an empirical examination of the influence of size and heterogeneity and natural packing. Eos Trans Am Geophys U 1989; 70: 110927.

[34] Lisle TE, Ikeda H, Iseya F. Formation of stationary alternate bars in a steep channel with mixed-size sediment: a flume experiment. Earth Surf Proc Landf 1991; 16: 463-469.

[35] Frederici B, Seminara G. On the convective nature of bar instability. J Fluid Mech 2003; 487: 125-145.

[36] Bathurst JC, Ashiq M. Dambreak flood impact on mountain stream bedload transport after 13 years. Earth Surf Proc Landf 1998; 23: 643649.

[37] Clayton JA. In: Ferrari DM, Guiseppi AR, Eds. Geomorphology and Plate Tectonics. New York, NY: Nova Science Publishers, Inc 2009; pp. 97-116.

[38] Ferguson RI, Cudden JR, Hoey TB, Rice SP. River system discontinuities due to lateral inputs: generic styles and controls. Earth Surf Proc Landf 2006; 31: 1149-1166.

[39] Davey C, Lapointe M. Sedimentary links and the spatial organization of Atlantic salmon (Salmo salar) spawning habitat in a Canadian Shield river. Geomorphology 2007; 83: 82-96.

[40] Dawson M. Sediment size variation in a braided reach of the Sunwapta River, Alberta, Canada. Earth Surf Proc Landf 1988; 7: 599-618.

[41] Newson MD, Large ARG. 'Natural' rivers, 'hydromorphological quality' and river restoration: a challenging new agenda for applied fluvial geomorphology. Earth Surf Proc Landf 2006; 31: 1606-1624.

[42] Wohl E, Angermeier PL, Bledsoe B, et al. River restoration. Water Resour Res 2005; 41: W10301.

[43] Clayton JA, Westbrook CJ. The effect of the Grand Ditch on the abundance of benthic invertebrates in the upper Colorado River, RMNP. River Res Appl 2008; 24: 975-987.

[44] Wilcock PR, Crowe JC. A surface-based transport model for sand and gravel. J Hydraul Eng 2003; 29: 120-128.

[45] Parker G, Hassan M, Wilcock P. In: Habersack H, Piegay H, Rinaldi M, Eds. Gravel Bed Rivers 6, New York, NY: Elsevier 2006; pp. 241289. 